\title{
2.5 Професійна підготовка майбутніх педагогів до інноваційної діяльності в інклюзивних умовах закладів дошкільної освіти
}

Орієнтація українського суспільства на демократичні принципи, реорганізація системи освіти на забезпечення рівних можливостей для здобуття освіти всіх без винятку громадян, зумовлюють необхідність впровадження нових прогресивних концепцій, запровадження в освітній процес сучасних педагогічних технологій, нового ставлення до формування професійних знань, умінь та навичок випускників закладів вищої освіти. Відповідно до Закону України «Про вищу освіту» перед викладачами університетів, які готують фахівців 3 напряму підготовки «Дошкільна освіта», «Спеціальна освіта (Логопедія)», «Початкова освіта», постає цілий ряд нових викликів, які потребують негайної реалізації [119].

Проблема підготовки фахівців дошкільної освіти висвітлена у працях провідних вчених (А. Богуш, Н. Гавриш. І. Дичківської, К. Крутій , Ю. Рібцун, Т. Поніманської та інших), спеціальної освіти (В. Бондаря, В. Синьова, А. Колупеєвої, А. Шевцова, М. Шеремети та ін.) [120].

Відповідні зміни щодо забезпечення інклюзивної освіти, на сьогодні, введено в законодавчі та нормативно-правові документи, що стосуються дошкільної, загальної середньої та вищої ланок освіти. «Інклюзивне навчання» це система освітніх послуг, гарантованих державою, як визначено в Законі «Про освіту», що базується на принципі недискримінації, врахуванні багатоманітностей людини, ефективному залученні та включені до освітнього процесу всіх його учасників». «Інклюзивне освітнє середовище»- сукупність умов, способів і засобів їх реалізації для спільного навчання, виховання та розвитку здобувачів освіти з урахуванням їхніх потреб та можливостей [121].

Інклюзивна освіта в закладах дошкільної освіти - педагогічна інновація, що знаходиться на стадії впровадження, а тому має немало протиріч. По-перше, це професійна непідготовленість педагогів дошкільних груп до роботи з дітьми 3 особливими освітніми потребами (відсутні знання). По-друге, академічна 
THEORETICAL FOUNDATIONS OF THE FUNCTIONING OF EDUCATION. WAYS TO IMPROVE THE EFFECTIVENESS OF EDUCATIONAL ACTIVITIES

перевантаженість дошкільних навчальних програм, які досить важко адаптувати до потреб дитини з вадами у розвитку. Скорочення змісту навчального матеріалу може полягати у модифікації навчального плану або освітніх цілей для конкретної дитини, внесенні змін до навчальних завдань, визначенні обсягу знань, які їй необхідно засвоїти. По-третє, архітектурна непристосованість споруд. Деякі особливості облаштування фізичного середовища зумовлені особливими потребами дітей (фізичними, психологічними), тому перш ніж відкривати інклюзивні групи, керівник навчального закладу повинен у контексті організації освітнього середовища чітко визначити (згідно статті 2 Конвенції ООН про права осіб з інвалідністю), основні принципи універсального дизайну: рівноправне використання; гнучкість користування; сприйняття інформації 3 урахуванням різних сенсорних можливостей; припустимість помилок; низький рівень фізичних зусиль; наявність необхідного розміру i простору [122]. По-четверте, необхідне доопрацювання нормативно-правої бази, є потреба додаткового фінансування інклюзивних закладів освіти, чітке регулювання системи методичного забезпечення інклюзивної освіти дітей дошкільного віку.

Позитивний вплив інклюзивної освіти демонструє досвід європейських країн. Вчені доводять, що діти, які мають нормативний розвиток, навчаються сприймати відмінності між людьми як нормальне явище, шанувати людську гідність, бути відповідальними за інших, уважними до потреб оточуючих. Залучення до масових навчальних закладів дітей 3 особливими потребами вимагає від усіх учасників цього процесу певного перегляду традиційних поглядів щодо мети, функцій, організації роботи закладу. Проте, до найактуальніших проблем успішної реалізації інклюзивного навчання належить питання професійної підготовки майбутніх педагогів до роботи в нових умовах закладу дошкільної освіти.

3 огляду на вище зазначене, на сьогодні є актуальною проблема підготовки майбутніх педагогів до інноваційної професійної діяльності в інклюзивних умовах закладів дошкільної освіти. 
THEORETICAL FOUNDATIONS OF THE FUNCTIONING OF EDUCATION. WAYS TO IMPROVE THE EFFECTIVENESS OF EDUCATIONAL ACTIVITIES

Особливої уваги заслуговує проблема підготовки вихователів дошкільних груп до роботи в умовах інклюзивної освіти, оскільки функції вихователя значно розширюються. Як зазначає Ю. Рібцун, в умовах логопедичної групи чи спеціального закладу дошкільної освіти, крім загальноосвітніх заходів, передбачених масовою програмою навчального закладу, повинен виконуватись цілий ряд специфічних корекційних завдань, спрямованих насамперед на усунення первинного мовленнєвого дефекту та вторинних психофізіологічних нашарувань. Водночас слід пам’ятати, що корекційно-виховний напрямок занять у логопедичній групі є першочерговим, а загальноосвітній - другорядним. На відміну від масового ЗДО, вихователь логопедичних груп приділяє значну увагу мовленнєвій роботі [120]. Тобто, крім основних (навчальної, виховної, розвивальної), вихователь в умовах інклюзивної групи повинен виконувати такі функції:

- просвітницьку (інформування громадськості про особливості інклюзивного навчання);

- $\quad$ рефлексивну (уміння розробляти показники для аналізу корекційно педагогічного процесу й пошуку шляхів його корегування);

- інноваційну(використання інноваційних технологій в роботі 3 дітьми 3 особливими потребами).

Для виконання цих функцій, вихователь дошкільних груп має володіти знаннями $з$ фахових дисциплін, методиками корекційної роботи 3 дітьмилогопатами та здоровими дітьми. Навчальна програма закладу вищої освіти повинна передбачувати для фахівців 3 дошкільної освіти уміння і навички складання індивідуальної програми розвитку для дитини з особливими освітніми потребами. Як зазначає А. Колупаєва, основна мета загальноосвітнього навчального закладу, в якому впроваджується інклюзивне навчання, - надання індивідуально-орієнтованої педагогічної, психологічної та соціальної допомоги дітям, що мають особливі освітні потреби [123]. Відповідно, в освітні навчальні програми спеціальності 012 «Дошкільна освіта» має бути включений блок «Особливості створення індивідуальної програми розвитку для дітей 3 
THEORETICAL FOUNDATIONS OF THE FUNCTIONING OF EDUCATION. WAYS TO IMPROVE THE EFFECTIVENESS OF EDUCATIONAL ACTIVITIES

особливими освітніми потребами». Індивідуальну програму розвитку створюють на основі навчальної програми яка затверджена навчальним закладом освіти i має такі розділи: загальні дані про дитину, особливості психофізичного розвитку, термін на який складається програма; студенти повинні вміти, залежно від складності порушень розвитку вивчати можливості та потреби дитини. За висновками фахівців інформаційно - ресурсного центру вихователі повинні узагальнити інформацію щодо впливу порушень розвитку дитини на її здатність до навчання та мати уяву про додаткові послуги педагогів, та інших фахівців, які необхідні дитині для засвоєння навчальної програми. Зміни до навчального змісту програми стосуються як його змісту, так і складності навчального завдання і ця нова функція вихователя повинна бути сформована під час аудиторних, практичних занять у закладі вищої освіти. У випадку, коли дитина переїжджає в інший район, новий педагог повинен отримати IНП і дізнатися, що саме необхідно для навчання й розвитку вихованця. Ознайомившись 3 IНП, батьки повинні розуміти: чому їхня дитина потребує особливого навчання; хто буде проводити навчання; де відбуватиметься навчання; тривалість навчання; програма оцінювання; скільки часу їхня дитина проводитиме в спеціальному навчальному закладі; які заходи здійснюватимуться для дитини, наприклад, професійна та фізична терапія, надання порад, консультацій, перевезення.

Виконуючи професійні функції вихователь має дотримуватись принципів роботи в інклюзивних групах. Серед таких принципів: індивідуалізації та диференціації (вихователь має знаходити підхід до кожної дитини, враховуючи ii особливість та працюючи за індивідуальною програмою розвитку, диференціювати завдання для дітей відповідної вікової групи); принцип єдності сенсорного, комунікативного, фізичного розвитку (у відповідності до потреб дитини); підтримка самостійної активності дитини (вихователі мають надавати дітям час на вільні ігри, діяльність, підтримувати дитину у ініціативі активності); міждисциплінарного підходу (освіта дитини з психофізичним рушенням вимагає комплексного, міждисциплінарного підходу до визначення впровадження методів і засобів іiі виховання, навчання і розвитку); принцип співпраці 3 
THEORETICAL FOUNDATIONS OF THE FUNCTIONING OF EDUCATION. WAYS TO IMPROVE THE EFFECTIVENESS OF EDUCATIONAL ACTIVITIES

родиною (тільки у спільній діяльності закладу дошкільної освіти з батьками діток може бути ефективний результат); принцип варіативності в організації процесів навчання і виховання (закладу дошкільної освіти і вихователю має надаватись право у виборі навчальної програми за якою працювати, форм i методів організації освітнього процесу).

Важлива складова успішного функціонування інклюзивної системи освіти - командний підхід. Однак, практика спільного викладання ще не стала загальноприйнятою в системі надання вищої освіти в Україні. Тому, вважаємо за необхідне введення теми: «Форми спільного викладання» в дисципліну «Дошкільна педагогіка», де розкрити особливості командної освітньої роботи в інклюзивній групі; диференційованого викладання (робота 3 великою та малою навчальними групами); паралельне викладання (навчальний матеріал однаковий, а методи навчання можуть бути різними). Наукові дослідження (Н. Дятленко, Н. Софій, О. Мартинчук, Ю. Найда) визнають співпрацю як найбільш корисний i доступний ресурс, який є в розпорядженні педагогів системи загальної освіти. Посаду асистента вчителя, вихователя введено в українське законодавство та відображено в ряді нормативно - правових документів [124]. Робота з асистентом вихователя потребує вміння вихователя використовувати практику спільного проведення навчальних занять, навички спільного планування та обговорення освітнього процесу. Очевидно, що система професійної підготовки майбутніх фахівців дошкільної освіти, яка проводиться у закладах вищої освіти повинна відреагувати на виклики сьогодення і внести відповідні зміни у освітні та робочі програми дисциплін [125].

Під час підготовки майбутніх вихователів у закладі вищої освіти має бути передбачена навчальна і виробнича практика у різних типах закладів дошкільної освіти. Викладачі-керівники практик мають знайомити майбутніх педагогів 3 можливими умовами подальшої професійної педагогічної діяльності в інклюзивних групах закладів дошкільної освіти. Така робота має включати попередньо надані теоретичні знання студентам, які згодом вони зможуть реалізувати на практиці. Тільки через занурення майбутніх педагогів в освітній 
THEORETICAL FOUNDATIONS OF THE FUNCTIONING OF EDUCATION. WAYS TO

IMPROVE THE EFFECTIVENESS OF EDUCATIONAL ACTIVITIES

процес закладу дошкільної освіти, студент зможе відчути різницю діяльності вихователя у звичайній та інклюзивній групі. Вихователі які вже із студентських років отримували знання про роботу з дітьми з особливими потребами зможуть у практичній діяльності допомогти дитині 3 особливими потребами, а не нашкодити їй. На сьогодні за останніми дослідженнями та опитуваннями вихователів закладів дошкільної освіти, результати свідчать про те що педагоги не готові до роботи з дітьми з особливими потребами, за думкою вихователів їм не вистачає теоретичних знань, практичних вмінь та навичок, психологічної готовності працювати у групі де багато діток, але водночас тримати у полі зору дітей з особливими освітніми потребами.

Відповідно до положення Про команду психолого - педагогічного супроводу дитини з особливими освітніми потребами в закладі загальної та дошкільної освіти, затвердженого наказом МОН України від 08. 06. 2018p. за № 609, потребує особливої уваги вивчення майбутніми фахівцями методики складання, змісту, форми та послідовності засвоєння дитиною дошкільного віку з ООП, компонентів освітньої програми з метою реалізації іiі індивідуальної освітньої траєкторії [126]. У зв’язку з наявністю такої навчальної дисципліни як «Логопедія», передбачено опанування студентами закономірностей формування мовлення, принципів аналізу мовленнєвих порушень, оволодіння методами та прийомами діагностики, корекції вад мовлення у дітей, однак, мало уваги приділяється практичній діяльності вихователів закладів дошкільної освіти. Так, інклюзивно-ресурсні центри які проводять комплексну оцінку 3 метою визначення особливих освітніх потреб дитини, в тому числі коефіцієнта іï інтелекту, розроблення рекомендацій щодо освітньої програми, надання психолого-педагогічних та корекційно-розвиткових послуг відповідно до потенційних можливостей дитини, а спеціалісти закладів дошкільної освіти не завжди кваліфіковано можуть їх використовувати. Педагогічна пропаганда психолого-педагогічних та корекційно-розвиткових послуг дітям з особливими освітніми потребами, які надають ІРЦ теж іноді відсутні в арсеналі навчально - виховної роботи закладу дошкільної освіти. 
THEORETICAL FOUNDATIONS OF THE FUNCTIONING OF EDUCATION. WAYS TO IMPROVE THE EFFECTIVENESS OF EDUCATIONAL ACTIVITIES

В командах психолого-педагогічного супроводу дитини 3 особливими освітніми потребами у закладах дошкільної освіти, а також психолого- педагогічних комісіях спеціальних закладів загальної середньої освіти приймають участь педагогічні працівники інклюзивно-ресурсного центру 3 метою моніторингу динаміки розвитку дитини не рідше, ніж двічі на рік. Особливостям співпраці вихователів з різними фахівцями необхідно приділити більше уваги, оскільки здійснення спільного викладання позитивно впливатиме на якість освітнього процесу в інклюзивній групі [127, с. 10].

Залучення батьків дітей 3 особливими освітнім потребами до педагогічного процесу має свою специфіку. Дуже важливою та незвичною для педагогів є участь батьків у роботі команди психолого - педагогічного супроводу кожної дитини 3 особливими освітніми потребами. Необхідно педагогам інклюзивних груп навчитися активно залучати батьків до освітнього процесу на етапі оцінювання рівня розвитку дитини, планування іï освітньої траєкторії, участі у різних навчальних видах діяльності. Однак, перш за все, їх потрібно навчити давати об'єктивну оцінку навчальним знання, вмінням та навичкам своєї дитини з урахуванням іiі освітніх потреб. Одним із відповідальних завдань, які постають перед батьками на цьому етапі $є$ створення індивідуальної програми навчання та виховання дитини на основі їі актуального рівня розвитку, з метою визначення освітніх цілей і навчальних завдань, для здійснення необхідних змін в освітньому процесі та забезпечення додаткових потреб дитини. Завдання закладу вищої освіти полягає у виборі форм, методів, нових педагогічних технологій навчання майбутніх спеціалістів роботі в нових умовах інклюзивної освіти. Батьки мають право отримувати інформацію про освітній процес, про місію навчального закладу, додаткові можливості та послуги. Педагоги повинні вміти регулярно та вчасно надавати батькам дітей 3 особливими освітніми потребами інформацію щодо прогресу в розвитку дитини та його навчальній діяльності. Батьківська спільнота повинна розуміти значення закладу дошкільної освіти для дитини, сприймати вихователів як об’єктів педагогічного колективу які допоможуть дитині у їі розвитку [129]. 
Отже, одним із пріоритетних завдань державної політики є створення умов для розвитку сучасної системи інклюзивної освіти в Україні. Залучення до масових навчальних закладів освіти дітей з особливими освітніми потребами вимагає від усіх учасників цього процесу перегляду традиційних поглядів на мету, завдання, функції, організацію роботи педагогічного колективу в умовах сьогодення. Професійна підготовка майбутніх педагогів в умовах закладу вищої освіти повинна враховувати таку важливу складову успішного функціонування інклюзивної системи освіти - командний підхід. Завдання - розкрити особливості командної навчально-виховної роботи в інклюзивній групі: диференційованого викладання, паралельного викладання та ін. Наукові дослідження визнають також співпрацю як найбільш корисний і доступний ресурс, тому посаду асистента вчителя, вихователя введено в українське законодавство та потребує відпрацювання система співпраці 3 додатковими фахівцями. Робочі програми відповідних дисциплін закладу вищої освіти мають передбачувати включення для фахівців з дошкільної освіти формування умінь і навичок складання індивідуальної програми розвитку для дитини з особливими освітніми потребами. Активна участь батьків в освітньому процесі є однією 3 важливих передумов інклюзивної освіти. 